Article

\title{
Sustainable Building Assessment of Colonial Shophouses after Adaptive Reuse in Kuala Lumpur
}

\author{
Karam M. Al-Obaidi ${ }^{1, *}$ (D) , Sim Li Wei ${ }^{1}$, Muhammad Azzam Ismail ${ }^{1}$ and Kenn Jhun Kam ${ }^{2}$ \\ 1 Center for Building, Construction and Tropical Architecture, Faculty of Built Environment, \\ University of Malaya, Kuala Lumpur 50603, Malaysia; simliwei94@gmail.com (S.L.W.); \\ ma.ismail@um.edu.my (M.A.I.) \\ 2 Faculty of Built Environment, Tunku Abdul Rahman University College, Kuala Lumpur 53300, Malaysia; \\ kamkennjhun@gmail.com \\ * Correspondence: karam@um.edu.my; Tel.: +60-3-7967-2459
}

Received: 28 June 2017; Accepted: 5 October 2017; Published: 13 October 2017

\begin{abstract}
Kuala Lumpur, as a major capital city, has undergone a drastic transformation in the past ten years. Many heritage buildings have been sacrificed for urban renewal projects. Those located in the touristic heritage zones within Kuala Lumpur were being converted by their owners into hotels and cafés to meet current demands to sustain their incomes. This approach, however, creates several physical and environmental issues within the new adaptation. The aim of this study is to evaluate the building performance of heritage shophouses that were adapted into budget hotels. The research focuses on two case studies in a strategic and historical location of Jalan Sultan, Kuala Lumpur. At the initial stage, interviews and physical surveys were done to determine the context of this study. The authors of this research then used a triangulation method through indoor environmental condition assessment, measurements of indoor environmental conditions and occupant survey to determine the indoor building performance after the adaption. Results showed that adaptive reuse heritage buildings can perform and meet new indoor environmental requirements, but many sensitive design judgments need to be made before the adaptive reuse renovation. The research found that the use of natural light, natural ventilation, recycled materials and water efficiency have been neglected and thus, they should be prioritized and preserved to ensure a successful change of use. Conserving existing heritage buildings, while incorporating new usages with acceptable comfort, is in line with the principle of sustainability.
\end{abstract}

Keywords: adaptive reuse; heritage building; colonial shophouse; sustainability; indoor environmental quality; Malaysia

\section{Introduction}

Malaysia has many heritage buildings and it is rich in culture and context [1]. There are many heritage sites with active conservation projects such as Kuala Lumpur, Penang, and Melaka. In 2005, the Malaysian Government established the National Heritage Act 2005 which was formerly known as the Antiquity Act 1976 [2] to consolidate all efforts in conserving tangible heritage such as buildings, in addition to intangible heritage such as performing arts, among others. According to the National Heritage Act 2005, adaptive restoration of heritage buildings " ... involves all or portion of the exterior restoration with the interior adapted to a modern functional use" [3]. Many heritage buildings in Malaysia went through this process, which can be termed as adaptive reuse. Shopsin [4] introduced this term to describe the process of providing a new function in an old building or a district if it involved many buildings. Douglas [5] stated that in order to change the building's capacity, function or performance, adaptive reuse includes any work to a building over and above maintenance to suit the new environment and necessities. It also works to improve the heritage building in terms of 
disabled facilities, fire safety, sound insulation, structural stability and thermal efficiency [6]. Adaptive reuse of heritage buildings definitely provides environmental benefits in the reuse of materials and structural elements, reduction of demolition waste and new carbon emissions, and saving of used energy [7-9]. Yung et al. [10] stated that globally, adaptive reuse of heritage buildings have been increasingly recognized as a sustainable approach to conservation [11]. However, there are many challenges to enhance sustainability, particularly where redevelopment pressures are immense in urban renewal districts in heritage cities of Southeast Asia [12] and especially in Malaysia.

Dian and Abdullah [13] mentioned that there are accelerating records of deterioration and abandonment cases in most heritage sites in Malaysia. In addition, there are no proper guidelines or legal protection regarding adaptive reuse, which causes the buildings to undergo uncontrolled renovation, alteration and conversion of spaces. In many cases, the economic part of the adaptive reuse has overwhelmed the environmental needs, and the sustainability of buildings has always been neglected. In addition, many modern technologies have been introduced in heritage buildings such as artificial lighting, security systems, fire alarm systems, disability access and climate control systems. Furthermore, Baker [6] stated that the common motivation for adaptive reuse includes the replacement of degraded finishes and component, accommodate space organization to new function as well as enhance the environmental quality and adjustment in building planning. Therefore, the lack of control in this approach leads to problems in indoor conditions. In fact, the conversions of spaces in colonial shophouses are usually decided on by the building owners, which involve structural and non-structural adaptation. Watson [14] stated that building suitability relating to the size and shape of the building requires careful examination to ensure it will meet the building owners' or clients' new requirements. Therefore, lack of knowledge in building conservation techniques and inappropriate adaptation can be detected, which consequently affects the quality of the indoor environment.

Highlighting the above issues, the authors of this study selected Jalan Sultan in Chinatown, Kuala Lumpur as a case study, based on the area redevelopment issues that alerted many people on the street in 2013. The "Save Jalan Sultan 2.0 (LIGHT a Lantern)" event was held at Jalan Sultan to commemorate and preserve the heritage of the antiquated buildings, as a result of the impact of a new transportation project called the Mass Rapid Transit (MRT), planned to propel the Greater Kuala Lumpur metropolitan area to be on par with other developed cities of the world. In fact, Jalan Sultan is located in the heart of Kuala Lumpur, with a distance of approximately $400 \mathrm{~m}$ from the Petronas twin towers, which were the tallest buildings in the world from 1998 to 2004.

In the past, tin mining workers, mainly from the Chinese community, were located to Jalan Sultan by the British colonial authorities through the rebuilding plan of 1884 (Figure 1). Shophouses were built along this street as well as along the two dominant thoroughfares running North and South, namely Jalan Bandar and Jalan Petaling, forming the Chinatown area, which is strategically located near the Klang River in the Kuala Lumpur city centre [15]. The architectural style of the shophouses in Chinatown was in contrast to the colonial buildings on the other side of the Klang River.

Shophouses along Jalan Sultan stood there for decades and witnessed the independence of Malaysia and the development of Kuala Lumpur as the federal capital. According to Loo [16], "The shophouses in Chinatown are so unique that they are closely associated with the Chinese, and sometimes to an extent representing the Chinese way of life and the 'race' itself." Although the building by-laws were in place, the British did not regulate the design style, so that Chinese builders constructed spaces and facades mainly based on the Chinese way [16]. Therefore, the shophouse architecture is aesthetically historic and forms part of the national heritage that must be conserved. The 'five-foot way' (walkway in front of the shophouses), internal air well, decorative façade, and decorative windows represent the typical features of Chinese shophouses, as shown in Figure 2. 


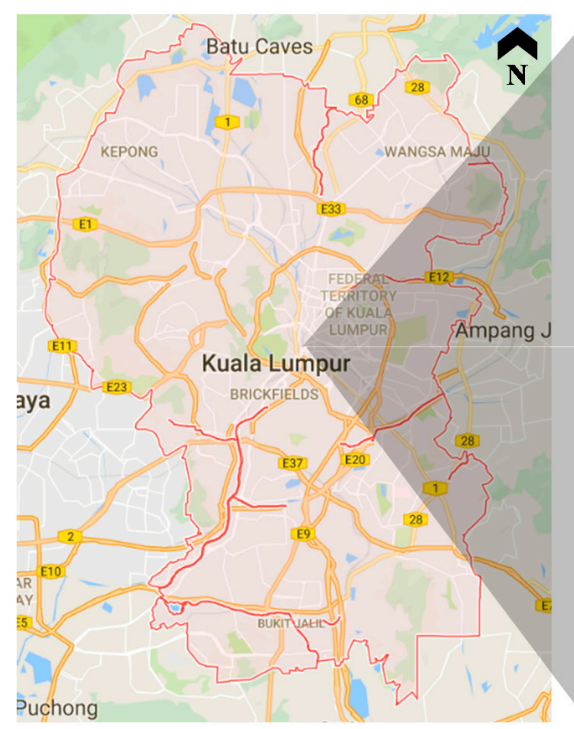

Kuala Lumpur Map

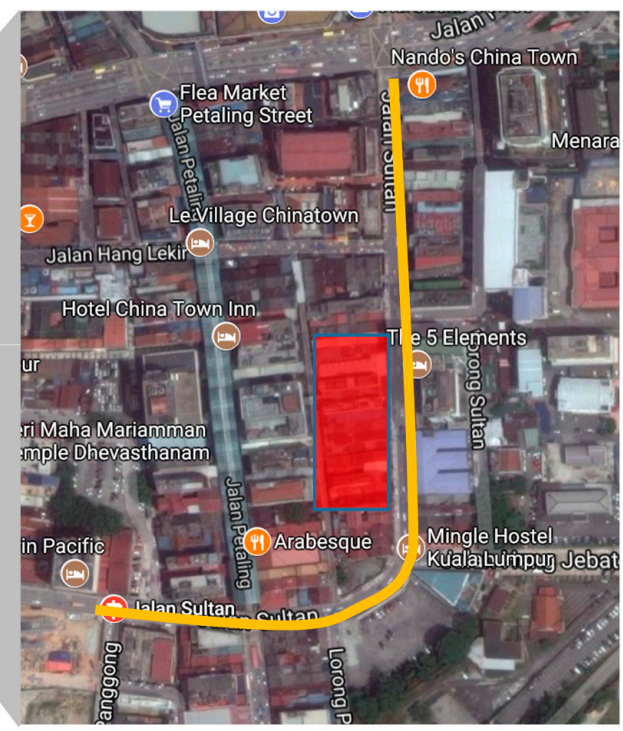

Jalan Sulatn $\quad$ Case study site

Figure 1. Location of case studies in Kuala Lumpur and Jalan Sultan (Google map, 2017).

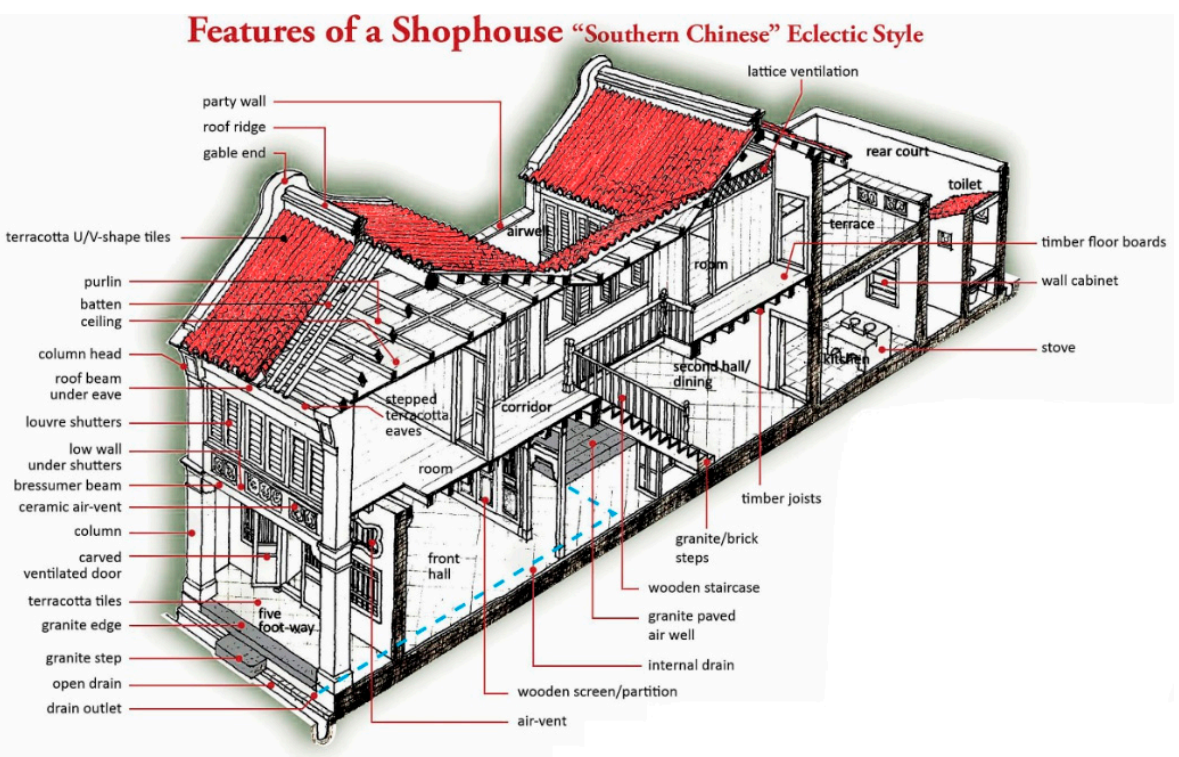

Figure 2. Section of a typical Chinese shophouse demonstrated by Tan [17].

The Chinese shophouse is mainly two to three floors in height, with a certain typical interior layout [15]. The shophouses are built along the street with an established uniform grid. The long rectangular floor plan of shophouses offers a narrow frontage. The ground floor, which faces the street, is for commercial purposes, whereas the rear section and upper floor of shophouses are for private use. The case studies sampled along Jalan Sultan were altered from their original function and went through extensive adaptation processes. Generally, most private heritage buildings along Jalan Sultan and Chinatown have been converted into hotels, cafés, bars, and restaurants to fit the modern needs of locals and tourists.

Malaysia Tourism Statistics stated that there were 25.7 million tourist arrivals in 2015, which contributed MYR69.1 billion into the local economy [18]. Hall et al. [19] stated that the tourism sector faces many crucial issues in sustainability, where it involves parties such as business, government, non-government organizations and many individuals who are seeking to minimize environmental 
and social impacts. Swarbrooke [20] stated that the hospitality sector is crucial and that there are four aspects of sustainable tourism, namely: new accommodation units' location and design; environment-friendly practice, such as energy conservation and recycling; sustaining employment and sustaining local culture, such as local cuisine. Therefore, new hotels need to comply with the principle of sustainability by using local building materials, which support the local industry, as well as considering the existing streetscape, by applying appropriate and contextual architecture style and building scale. The classification of hotels is mainly based on the location, function and special characteristics of the area [21]; many of the hotels along Jalan Sultan are budget hotels and backpackers' inns that should be assessed for their compliance with the principle of sustainability. Normally, backpackers' traveler accommodation offers dormitory rooms and private rooms to accommodate the needs of backpackers. According to Hannam and Ateljevic [22], backpacker tourists only need minimal infrastructure as they are not interested in the mass tourist needs, including many amenities, cafés, and transportation; thus, backpacker tourism is low in budget and has a low impact on the environmental and cultural characteristics of a locality.

A sustainable building can be achieved when it meets certain criteria such as the reduction of energy consumption, cost, and total embodied project energy [9]. Douglas [5] and Remøy and van der Voordt [23] stated that structural stability, weather tightness and overall performance of the shophouses are influenced by factors such as structural failure, physical deterioration, dilapidation and even urban blight. Conejos et al. [24] determined the various challenges encountered in undertaking adaptive reuse. Department of environment and heritage [9], Latham [25] and Wilkinson et al. [26] defined adaptive reuse as the restoration of the building's value to a place or community, and that it is a strategy that extends the building's physical and social functions by giving it a new purpose while still conserving its historic and cultural significance. Fournier and Zimnicki [27] developed adaptive reuse guidelines that integrate the goals of sustainable design and historic preservation. Snyder [28] and Conejos et al. [29] defined green adaptive reuse where new technologies are incorporated into heritage buildings.

Therefore, adaptive reuse is very important in Malaysia as it helps to save heritage buildings from being demolished to satisfy modern needs. The aim of this study, then, is to evaluate the building performance of heritage shophouses that were adapted into budget hotels. This study targets only shophouses that were converted into budget hotels located along Jalan Sultan; its aim is to prove that these selected buildings can perform to meet the comfort needs of their occupants and the new building use. The study is limited to only an investigation after the adaptive reuse stage, without requiring a comparison before the adaptive reuse, as the building use is different.

\section{Methodology}

In this research, two case studies were selected to identify the performance of buildings that were converted into budget hotels, as shown in Figure 3. These two buildings have significant historical value, a similar history and are both located on the same street. Building A is a three storey Neo Classical building and was built in 1927. It originally served as the Selangor and Federal Territory Grocer's Guild. The ground floor of this building functioned as a commercial area, while the first and second floors served for private use in the past. Building B is a double storey Strait Eclectic colonial shophouse and was built around 1900. This shophouse has undergone a large scale renovation whereby three floors were added to the back of the original structure to become a budget hotel.

Many studies have been conducted on adaptively reused buildings with different approaches that included research methods such as case studies, interviews, model for decision making, comparative case studies and more $[8,10,13,23,30-35]$. Previous studies indicated a number of different technical and systematic approaches to evaluate the potential of adaptive reuse of buildings. However, they do not clearly assess the different sustainability dimensions [36]. Wilkinson [37] interpreted the Arup publication, 'Existing Buildings: Survival Strategies', which sets out Arup's thinking in regards to decision-making and building adaptation, and produced a model to represent the Arup philosophy. 
The Arup model is a paper-based evaluation that considers the physical and environmental aspects of the decision-making without any weightage, that distinguishes the importance of one indicator to another; overall, though, this model can be used in conjunction with other assessment methods such as the Green Building Index (that was developed for the Malaysian context) to conduct a more comprehensive assessment of buildings [38].

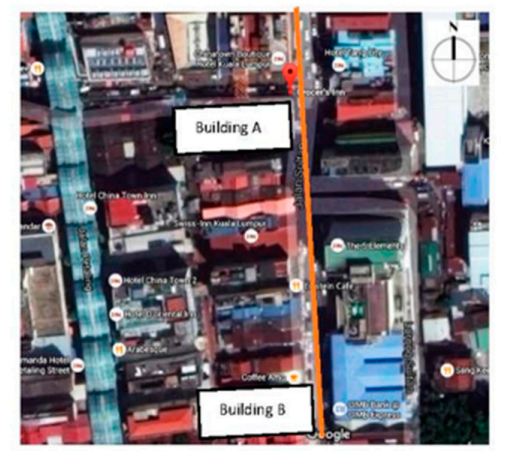

(a) Location of Building A and Building B in Jalan Sultan



(b) Building A

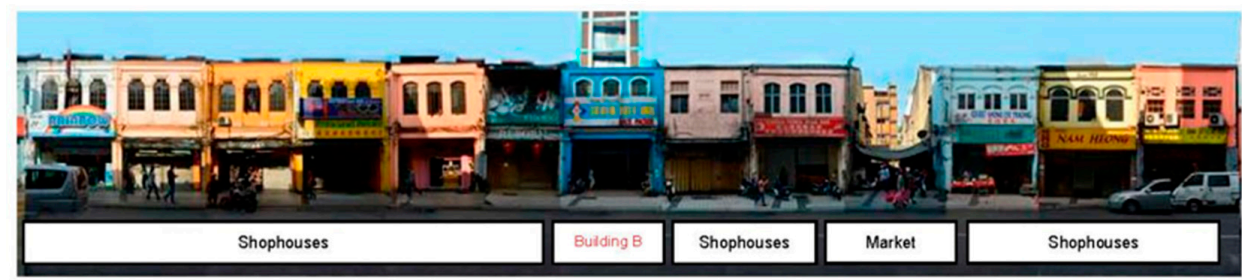

(c) Building B

Figure 3. The relation of Building A and Building B with context (Google map, 2017).

Therefore, a quantitative research methodology was selected to obtain the relevant data. A triangulation method was applied through indoor environmental condition assessment, measurement of indoor environmental condition and building occupant survey. Initially, interviews and physical surveys were conducted to understand the brief history of the case studies, determine the significance of their architectural styles and building features, and the ensuing renovation process. Then, an indoor environmental assessment was carried through a checklist that was adopted from the Green Building Index (GBI) and a matrix of building condition and performance by Arup (2008), forming 20 assessment criteria which are grouped into four sections (Table 1). The researchers were then able to assess the actual condition after adaptive reuse, such as air quality with ventilation, lighting, visual and acoustic requirements, materials and resources, as well as water efficiency. All assessment criteria requirements were rated on a scale of 1-3 according to its availability and functionality of a feature/equipment where: (1) indicated not available, (2) indicated moderate as available but not functional, and (3) indicated available and fully functional.

In addition, the indoor environmental conditions of both case studies were monitored using four HOBO data loggers as shown in Figures 4 and 5. Each data logger was equipped with sensors to 
record air temperature, air humidity, air velocity, and light intensity readings. The time interval for readings was $15 \mathrm{~min}$. All data loggers were set to record from 8 a.m. to 6 p.m. at two locations: (1) the lobby at the ground floor and (2) a hotel room on the first floor of each selected building. All data loggers were placed at the human seating level of $800 \mathrm{~mm}$ from the floor [39-42].

- Location A1: Lobby (Ground Floor of Building A)

- Location A2: Room (First Floor of Building A)

- Location B1: Lobby (Ground Floor of Building B)

- Location B2: Room (First Floor of Building B)
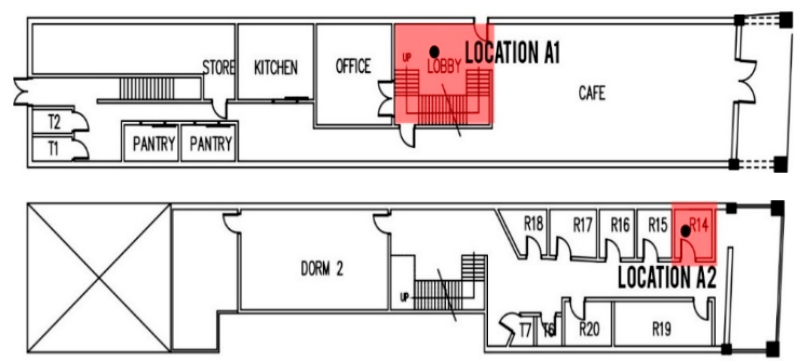

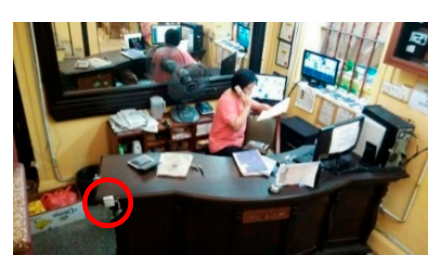

(A1) Ground Floor

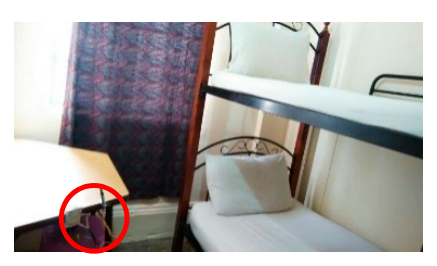

(A2) First Floor

Figure 4. Location of data loggers in Building A.
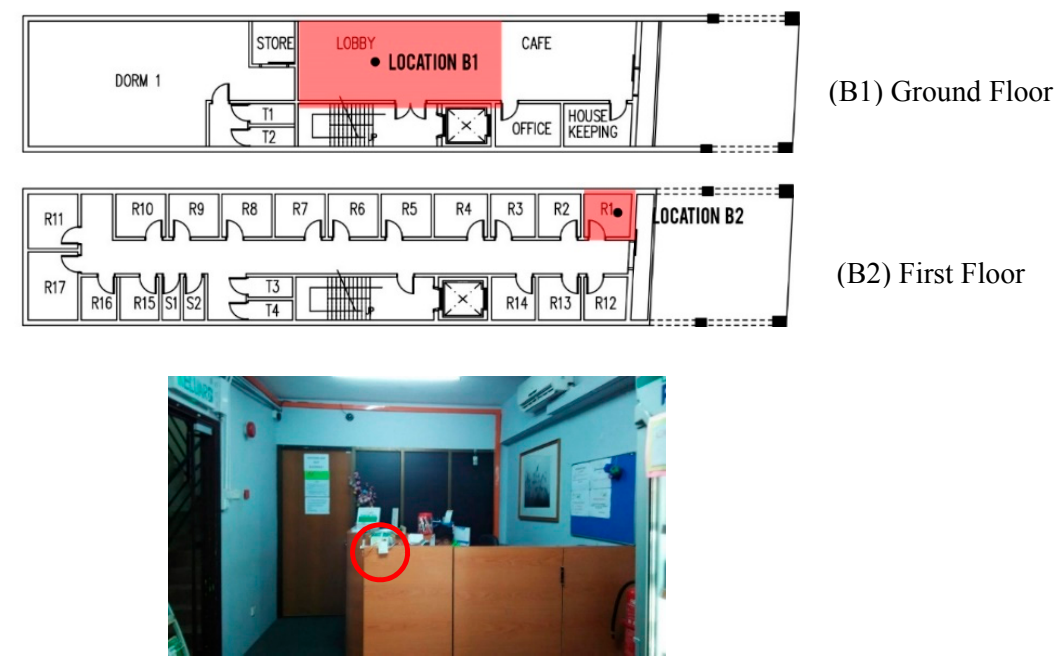

Figure 5. Location of data loggers in Building B.

In order to verify the monitored indoor environmental condition results, outdoor weather data was retrieved from a nearby weather station during March 2016. To add another dimension to this study, a 2-page questionnaire was prepared and distributed at both case studies involving 10 respondents. The questions within the survey were categorized into four main sections which are respondent information, environmental condition evaluation (at the lobby and hotel room), occupant's behavior, and pollution evaluation. A 5-point Likert scale was used to rate the respondents' daylight comfort, 
temperature, air velocity, air humidity and environmental pollution. In order to maintain the research validity, the evaluation part targeted only the building owners and staff who occupied the buildings daily, in order to provide evidence that is more persuasive. After all data were collected, they were analyzed and synthesized.

\section{Results and Analysis}

\subsection{Indoor Environmental Assessment}

An indoor environmental assessment was carried out in Building A and Building B. Specific factors were selected to assess the actual conditions after adaptive reuse, such as air quality with ventilation, lighting, visual and acoustic requirements, materials and resources, as well as water efficiency. Table 1 below shows the condition in Building A and Building B.

Table 1. Indoor environmental assessment in Building A and Building B.

\begin{tabular}{|c|c|c|c|}
\hline No. & Criteria & Building A & Building B \\
\hline \multicolumn{4}{|c|}{ Air Quality and Ventilation } \\
\hline 1 & Fully natural ventilated spaces & 0 & $\times$ \\
\hline 2 & Provide mechanical ventilation and air conditioners & $\bullet$ & $\bullet$ \\
\hline 3 & Provide auto controlled indoor temperature system & $\times$ & $\times$ \\
\hline 4 & Controlling moisture and humidity & $\bullet$ & • \\
\hline 5 & Prohibit smoking in the building & $\bullet$ & $\bigcirc$ \\
\hline \multicolumn{4}{|c|}{ Lighting, Visual and Acoustic } \\
\hline 6 & Provide sufficient levels of daylight for occupants & O & $x$ \\
\hline 7 & Provide blinds to prevent glare & $\bullet$ & - \\
\hline 8 & Provide artificial lighting & • & - \\
\hline 9 & Provide flexible lighting controls & $\bullet$ & $\bullet$ \\
\hline 10 & Provide energy saving lightings such as LED light and etc. & $\bigcirc$ & $\times$ \\
\hline 11 & Provide motion sensors & $\times$ & $\times$ \\
\hline 12 & Maintain internal noise levels at an appropriate level & $x$ & $x$ \\
\hline 13 & Use acoustic materials to reduce noise & $\times$ & $\times$ \\
\hline \multicolumn{4}{|c|}{ Material and Resources } \\
\hline 14 & Used recycled materials & $\bullet$ & $\times$ \\
\hline 15 & Provide recycling facilities & $x$ & $\times$ \\
\hline 16 & Promote and encourage waste minimization among occupants & 0 & $x$ \\
\hline 17 & Encourage waste sorting, collecting, quantifying, monitoring and recycling & $\bullet$ & $\times$ \\
\hline \multicolumn{4}{|c|}{ Water Efficiency } \\
\hline 18 & Promote water recycling & $x$ & $x$ \\
\hline 19 & Encourage rainwater harvesting & $x$ & $\times$ \\
\hline 20 & Provide dual flush cistern & $\times$ & $\times$ \\
\hline
\end{tabular}

Note: $\times=$ Not available, $\bigcirc=$ Available but not functional, $\bullet=$ Available and fully functional.

In the ventilation and air quality section, there are five main requirements that were rated and assessed with reference to the GBI assessment list. For the section of fully natural ventilated spaces, both case studies do not meet this requirement. However, Building A has available elements but are not functional, while Building $B$ received the lowest rating due to being fully dependent on air-conditioning systems. In addition, both case studies met the highest rating of functionality in providing mechanical ventilation and air-conditioning. However, both shophouses are not equipped with automatic controlled indoor air temperature system.

In Building A, mechanical ventilation such as fans are used to ventilate the interior public spaces such as the café, lobby, kitchen and even the corridor, as shown in Figure 6. The air-conditioners are only operated during the afternoon period in the café to provide a pleasant dining environment for the guests. Natural ventilation and fans are used in other parts of the day to reduce the operational cost. The hotel rooms in Building A are equipped with a fan and air-conditioners which allow the 
guests to select their preferred type of ventilation as shown in Figure 6. In addition, smoke vents are provided in the kitchen, as well as openings in the toilets to remove unpleasant smell and moisture from the building.

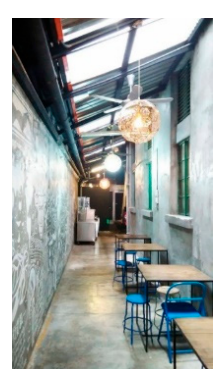

(a) Corridors

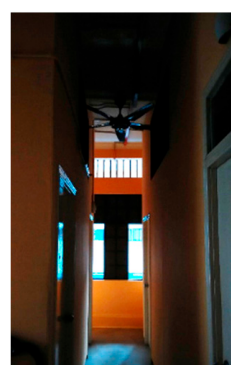

(b) Corridors

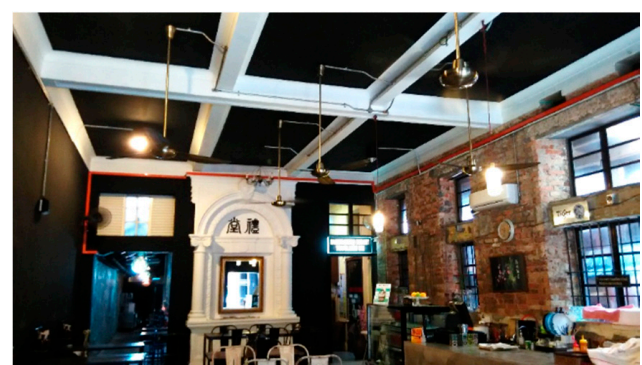

(c) Café

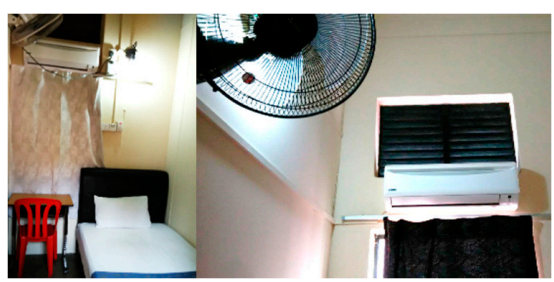

(d) Rooms

Figure 6. Types of mechanical ventilation in corridors, café and rooms in Building A.

On the contrary, all spaces in Building B are entirely air-conditioned as shown in Figure 7. This building only has openings on the front and back facades. Side openings are not provided on the wall of the additional floors. During the adaptive reuse renovation, the courtyard area which was originally situated in the middle of the building was fully covered with new suspended floors. It was also found that Building B now consumes more electricity, as previously recorded by the building owner. All air-conditioning systems are positioned in the corridor while wall-mounted mechanical air vents are provided to distribute cold air into each hotel room. More air vents are provided at the toilets and shower rooms. For both case studies, neither obvious dampness on the indoor surfaces nor moisture was visually spotted in the interior spaces.

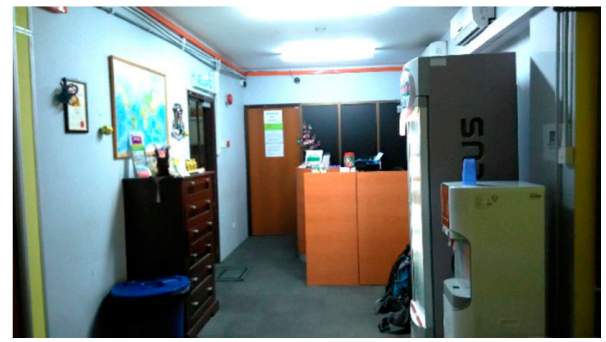

(a) Lobby of Building B

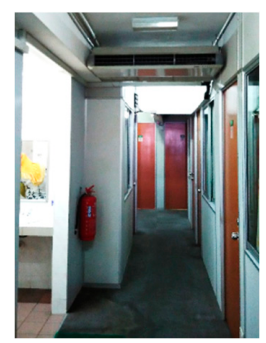

(b) Air-con at corridor

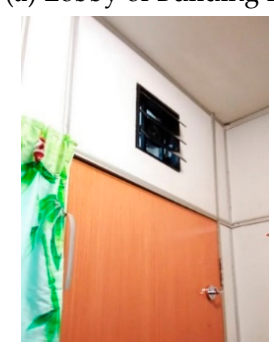

(c) Air vent in room

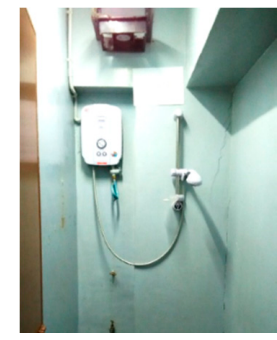

(d) Air vent in shower room

Figure 7. Building condition in Building B. 
For Lighting, Visual and Acoustic section in the indoor environmental assessment, there are eight main requirements that were assessed. Building A shows more functional openings which were maintained, and provides sufficient level of daylight for the occupants as compared to Building B (Figure 8). Inadequate amount of openings at Building B, as mentioned earlier, plus the deep building plan causes the interior of this building to have a low level of natural light. It was also found that not all windows provided in each room are functional; they only act for decorative purposes. Both case studies provided flexible lighting control and blinds to prevent glare which meet the second and fourth requirements. In addition, energy saving lighting, such as LED lighting, was found in Building A, however, they were not functional, while Building B gained a zero rating for this assessment. In addition, both shophouses do not provide any motion sensors to further reduce the electricity usage.

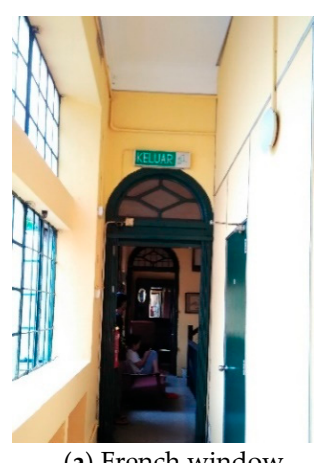

(a) French window

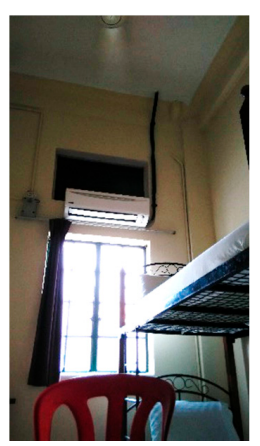

(b) Window in room

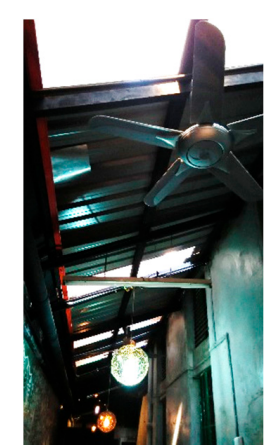

(c) Skylight in roof

Figure 8. Architectural features in Building A.

On the other hand, Building A has natural light in most of the spaces in its interior, especially along the corridor and hotel rooms. The original French windows, louvers, and railings were preserved to promote natural light to the interior. In order to prevent glare, blinds were provided for occupants to adjust according to their preferences in the hotel rooms. In addition, the corridor was designed with a skylight to bring in natural light to indoor spaces. Moreover, the courtyard at the mezzanine floor also allowed more natural light to the interior. Artificial lights were only used in public areas, especially at the ground floor to provide sufficient lighting condition for the guests. Throughout this building, LED light bulbs were used in some of the spaces to create a desirable atmosphere and to promote energy efficiency. However, fluorescent light is the dominant type of artificial lighting system in Building A.

In Building B, the indoor spaces have fewer openings, as the building is hemmed in on both sides in a middle along the Jalan Sultan. From the assessment is found that Building B depends entirely on artificial lights as the structural adaptation of the building is not well-designed. Therefore, natural daylight is unable to reach the interiors which cause the building to use more energy for lighting. Fluorescent troffers are used on the staircase area (Figure 9) while parabolic louver fluorescent troffer and fluorescent light can be noticed along the corridor and rooms.

Both Building A and Building B located along a street transform into a flea market and food street every morning, which contributes heavily towards noise pollution and disturbance to the surrounding building occupants. Unfortunately, there are no appropriate strategies practiced in both heritage buildings to improve the acoustic comfort of occupants. It was found that noise control was not an important concern when the adaptive reuse was carried out. In fact, the hotel rooms at both buildings were separated only by drywall (gypsum panel) with poor acoustic performance allowing noise to transmit between rooms.

In the Materials and Resources section, there are four main requirements that need to be met. Through on-site observation, recycled building materials and furniture were used in Building A, which met the first requirement. Recycling bins were not provided, which did not comply with the second requirement. However, the old floor tiles were maintained and there were many recycled furniture in 
Building A which created a cozy atmosphere. In addition, the wall plaster was removed to create a rustic and raw effect in the front door café. These actions were assessed as sustainable design approach which met the third requirement. In addition, Building A also practices waste sorting, collecting, quantifying, monitoring and recycling, which meet requirement 4 . Building $\mathrm{B}$, however, has no particular recycling plans or strategies which were practiced in during adaptive reuse renovation. The original roof structure was demolished and a new structure was built directly on the top of this shophouse. New materials were used in the construction, while parts of the original structure were demolished to build the additional structure. As for effective strategies in water use, there were no water efficiency measures such as water recycling, rainwater harvesting and dual flush cisterns at the toilets at both buildings.

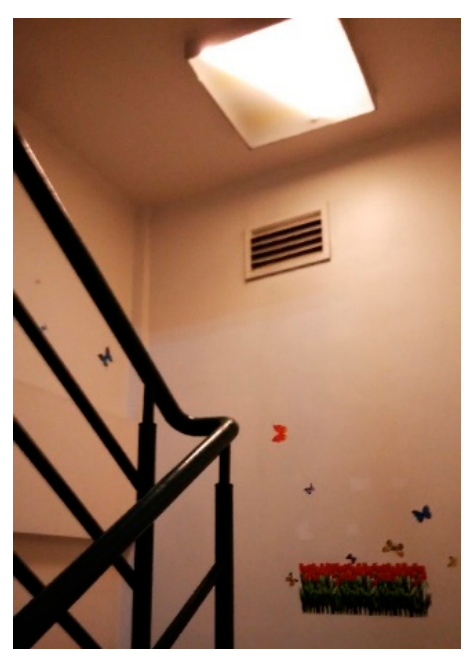

Figure 9. Lensed fluorescent troffer in Building B.

\subsection{Measurement of Indoor Environmental Conditions}

This section presents one day of data which represents a typical clear and sunny day in Kuala Lumpur. Figure 10 shows the air temperature of Kuala Lumpur on 18 March 2016 which was recorded and collected from a nearby weather station. The records showed that the air temperature ranged between $28^{\circ} \mathrm{C}$ and $34{ }^{\circ} \mathrm{C}$ in the $24 \mathrm{~h}$ cycle and the average air temperature was approximately $30^{\circ} \mathrm{C}$. Besides this, the average air humidity for the same day as recorded by the same weather station was approximately $76 \%$ while the maximum was $89 \%$ and minimum $39 \%$.

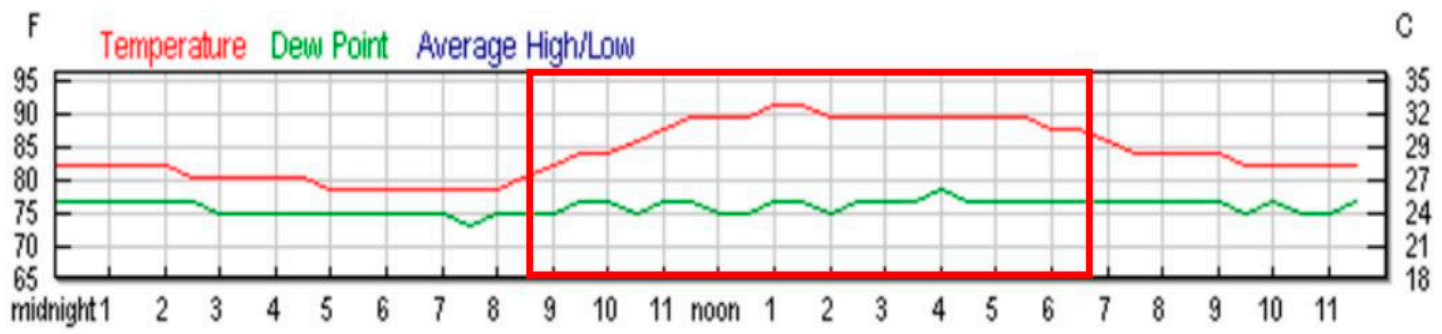

Figure 10. Air temperature in Kuala Lumpur on 18 March 2016.

\subsubsection{Indoor Environmental Condition in Hotel Lobbies}

The indoor environmental condition in Building A and Building B were analyzed from the monitored results. According to Malaysia Standard 1525:2014, the optimum and comfortable temperature in a space in Malaysia should be around $24-28{ }^{\circ} \mathrm{C}$. Monitored results showed that the mean air temperature of location A1 and B1 were slightly higher than the optimum comfortable 
temperature range. According to Figure 11, the indoor air temperature at location of A1 recorded an average air temperature about $31.92{ }^{\circ} \mathrm{C}$ and the indoor air temperature fluctuated in a range between $30.04{ }^{\circ} \mathrm{C}-32.43^{\circ} \mathrm{C}$, due to reliance on fans for ventilation. At location B1 however, it was stable at around $27^{\circ} \mathrm{C}$ as the lobby was situated in a fully air-conditioned space. From these findings, it was noticed that the indoor air temperature in lobby of both shophouses was quite stable throughout the recorded day and was not influenced by the outdoor air temperature.

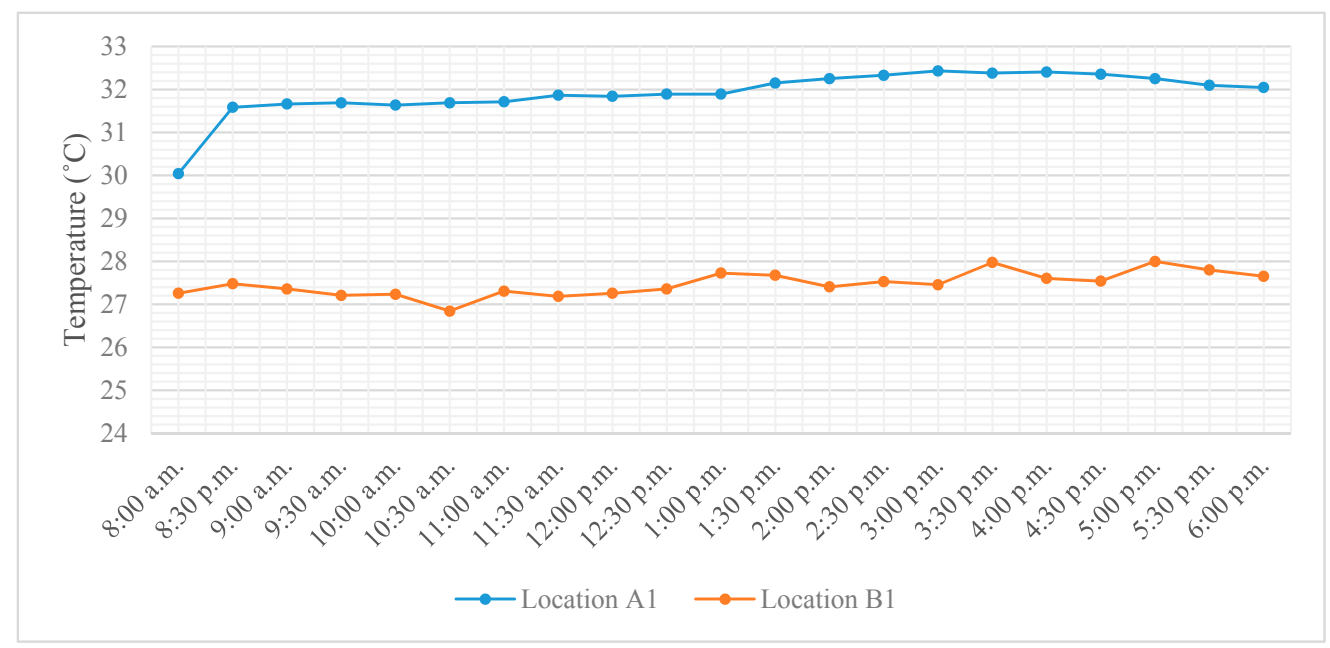

Figure 11. Indoor air temperature in the lobby of Building A (Location A1) and Building B (Location B1).

Relative humidity $(\mathrm{RH})$ also plays an important role in achieving indoor comfort. As shown in Figure 12, location A1 and B1 started the day with the highest level of RH. RH at location A1 started at $73.28 \%$ which gradually decreased to the lowest level at $59.22 \%$ at 3:00 p.m. The RH level raised after 3:00 p.m. to $69.13 \%$ at 6:00 p.m. Overall, the mean indoor RH at location A1 was around $66.23 \%$. In opposite, the RH of location B1 started with $73.66 \%$ and it gradually decreased until 10:00 a.m. then fluctuated until 1:00 p.m. The recorded RH increased steadily after 1:00 p.m. At the end, location A1 and location B1 recorded similar levels of relative humidity that ranged between $55-70 \%$ that is slightly above the requirement for comfort condition. The recorded RH levels at both location A1 and B1 are within the recorded outdoor RH levels of between $39 \%$ and $89 \%$ as mentioned earlier. This is due to the use of mechanical ventilation and air-conditioning at both locations.

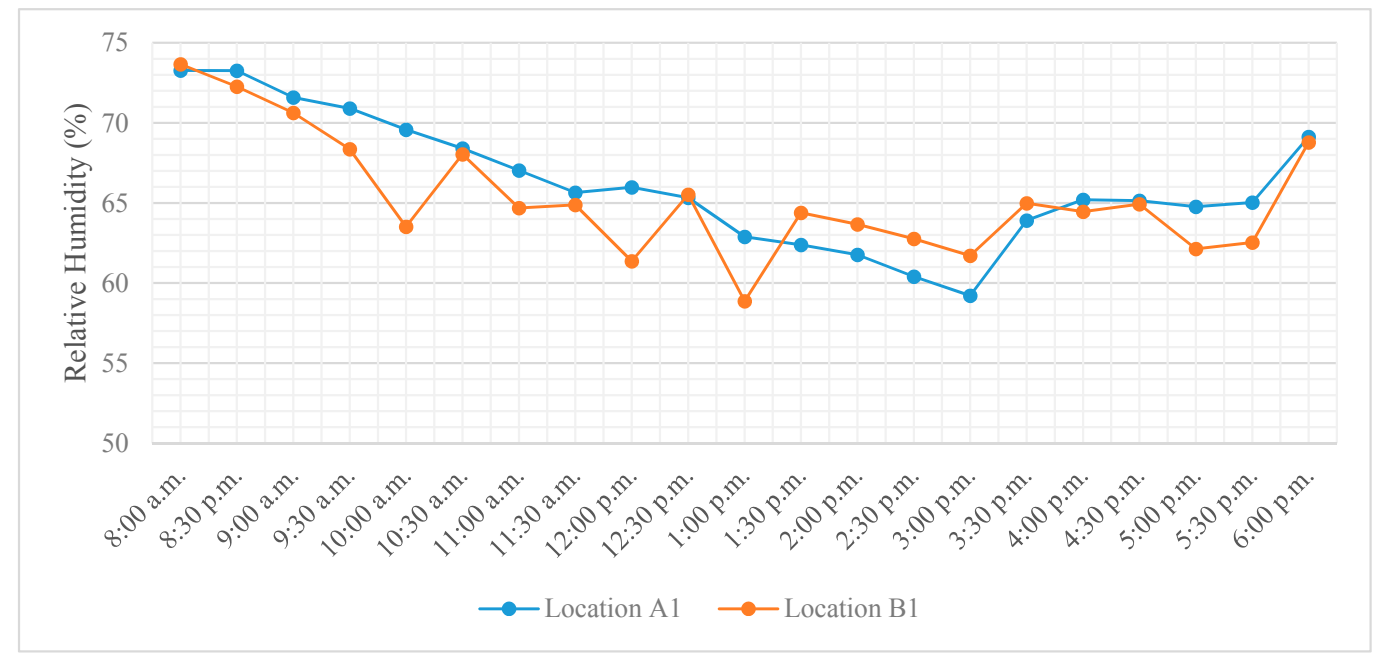

Figure 12. Indoor relative humidity in the lobby of Building A (Location A1) and Building B (Location B1). 
In Figure 13, the light intensity at location A1 and location B1 were within the acceptable level of 250 Lux for easy office task in the lobby area. The lowest light intensity received at location A1 was 208.9 Lux, while the minimum light intensity in location B1 was 201.0 Lux. The maximum light intensity in location A1 was slightly higher than location B1, which was 284.6 Lux at 11:30 a.m., while location B1 had the highest light intensity of 264.1 Lux at the same time. The mean light intensity of location A1 was also slightly higher than location B1, as the lobby of Building A has more openings as compared to Building B.



Figure 13. Indoor light intensity in the lobby of Building A (Location A1) and Building B (Location B1).

Figure 14 shows the air velocity at Building A compared to Building B. The air velocity at location A1 fluctuated in the range of $0.13 \mathrm{~m} / \mathrm{s}$ to $0.28 \mathrm{~m} / \mathrm{s}$, in which it reached the highest speed of $0.28 \mathrm{~m} / \mathrm{s}$ at 1:00 p.m. The air velocity at location A1 dropped significantly to $0.13 \mathrm{~m} / \mathrm{s}$ from 2:30 p.m. to 4:30 pm and increased up to $0.23 \mathrm{~m} / \mathrm{s}$ afterwards. Besides this, the air velocity at location B1 steadily remained between $0.05-0.10 \mathrm{~m} / \mathrm{s}$ as air-conditioning was used. The mean air velocity at location A1 was around $0.21 \mathrm{~m} / \mathrm{s}$, which was higher compared to the mean air velocity at location B1 (0.07 m/s). According to Malaysia Standard MS 1525:2014, the air velocity in the room should be around 0.10-0.50 m/s. Therefore, the air velocity in Building A meets the requirement of comfort while air velocity in location $\mathrm{B} 1$ was below the range.

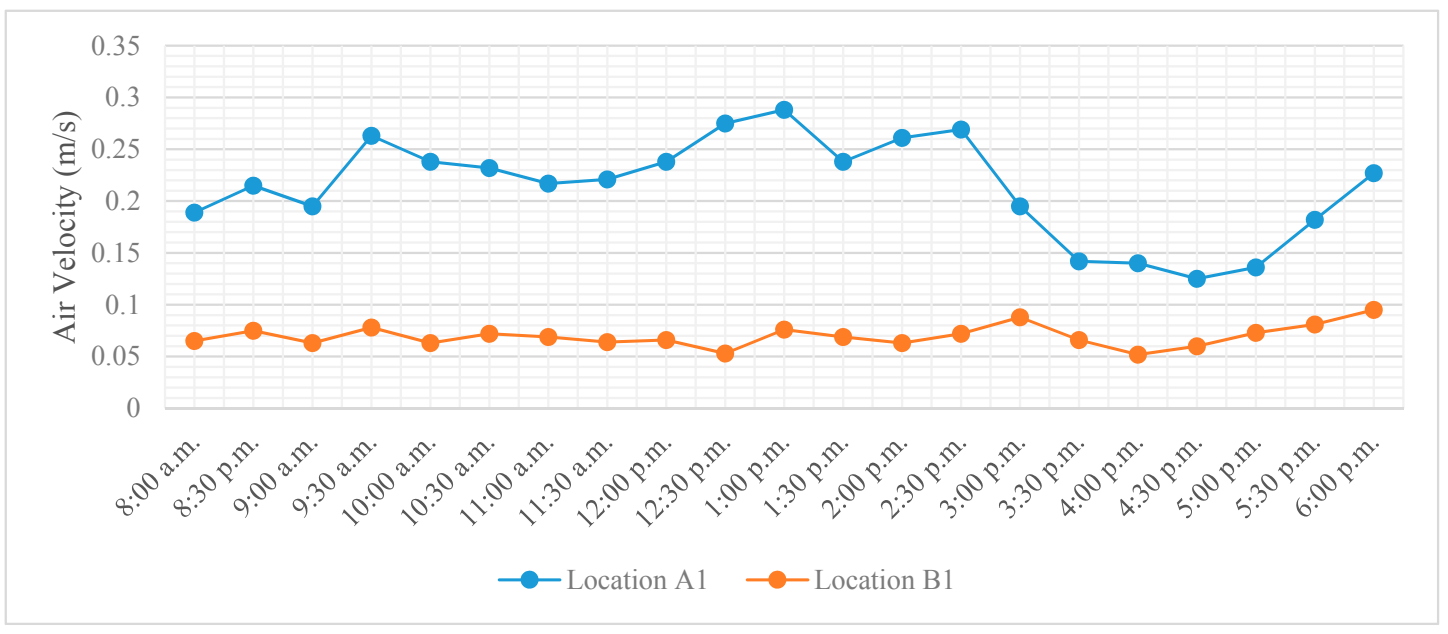

Figure 14. Indoor air velocity in the lobby of Building A (Location A1) and Building B (Location B1). 


\subsubsection{Indoor Environmental Conditions in Hotel Rooms}

In this section, a hotel room facing East and located on the first floor of each case study buildings were investigated. During the monitoring period, neither artificial lighting nor mechanical ventilation was operated to capture the passive condition of each room. Again, indoor environmental factors such as air temperature, relative humidity, light intensity and air velocity were analyzed to determine the performance of the studied case studies.

According to Figure 15, the overall air temperature in location A2 was higher than location B2 as location B2 was exposed to nearby corridors that were air-conditioned. Nevertheless, both of room air temperatures were above the optimum comfort temperature standard throughout the day. The air temperature at location A1 increased steadily from 10:00 a.m. to 6:00 p.m. where it finally reached $32.00^{\circ} \mathrm{C}$. Similarly, air temperature at location B1 increased from 10:30 a.m. to 6:00 p.m. and finally reached $30.12{ }^{\circ} \mathrm{C}$. The mean air temperature at location $\mathrm{B} 2$ was $28.54{ }^{\circ} \mathrm{C}$ which was lower than the mean air temperature at location $\mathrm{A} 2$ which was $31.16^{\circ} \mathrm{C}$.

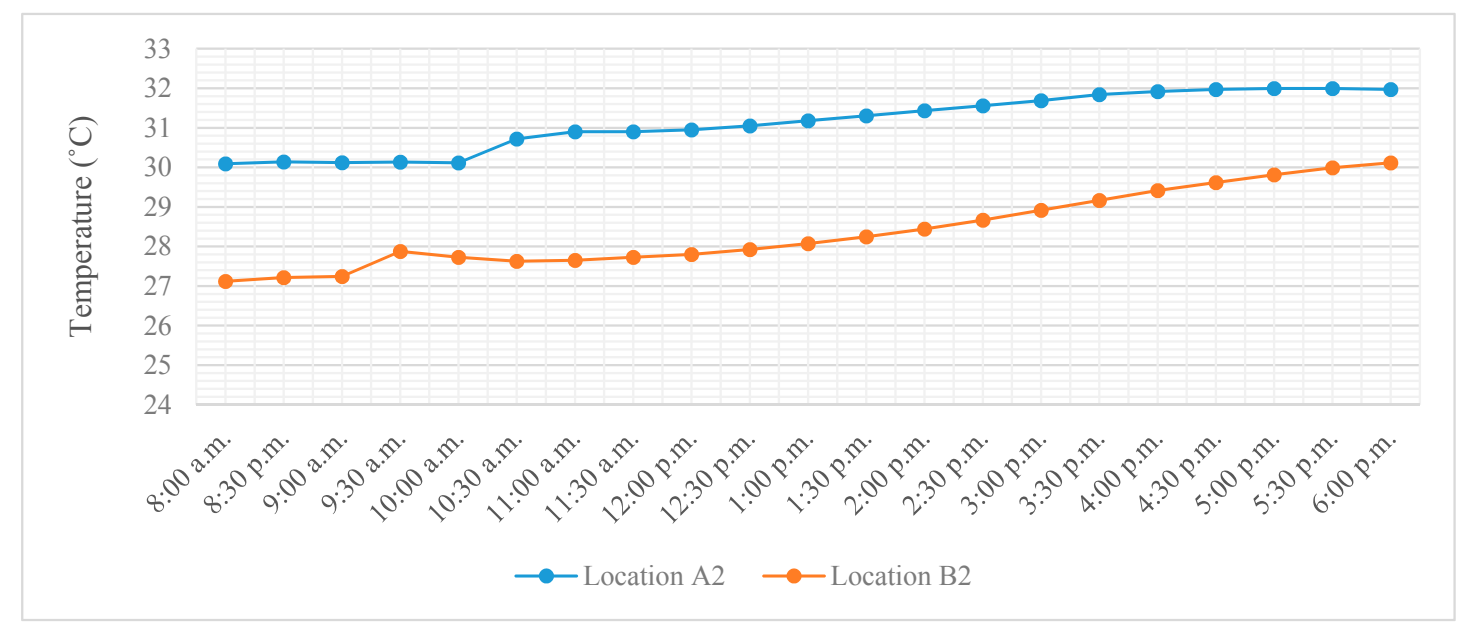

Figure 15. Indoor air temperature in the room of Building A (Location A2) and Building B (Location B2).

According to Figure 16, the overall mean $\mathrm{RH}$ at locations A2 and B2 were similar at $68.58 \%$ and $68.54 \%$ respectively. In the morning, the highest relative humidity was $73.81 \%$ at location A2 while the highest at location B2 reached $75.30 \%$ in the morning. Then, the RH decreased steadily throughout the day at both locations. Overall, the RH level at both locations was as slightly above the MS 1525:2014 standard.

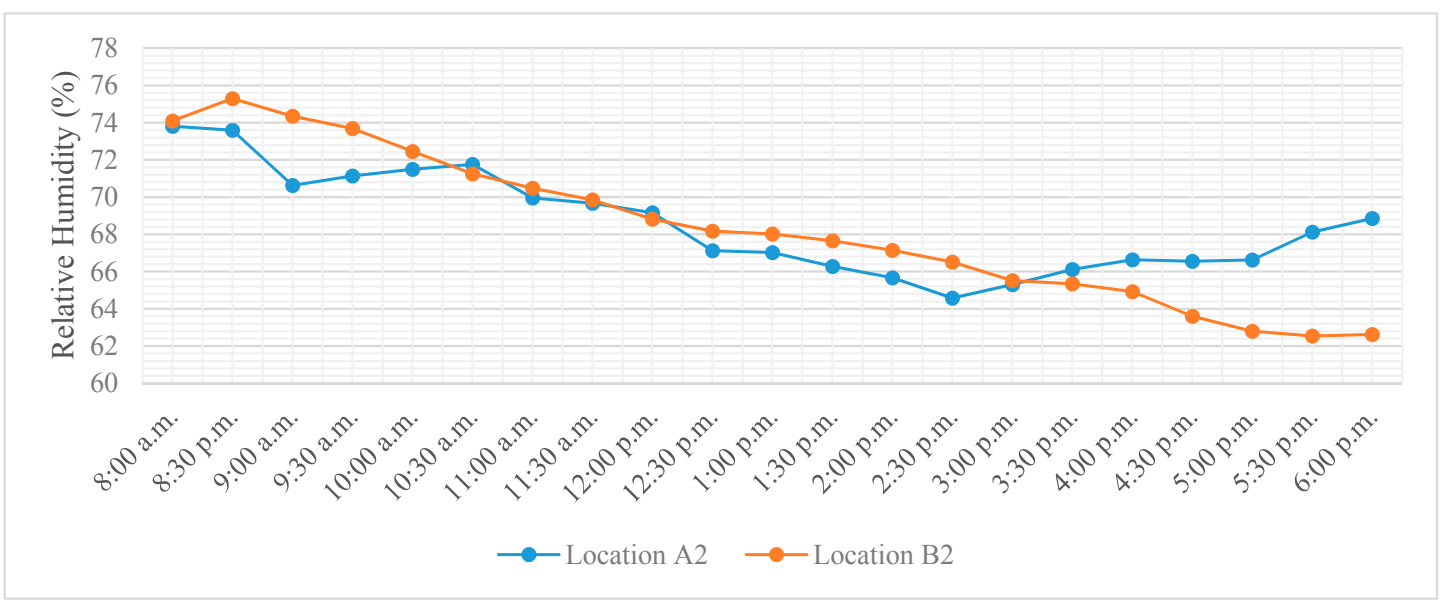

Figure 16. Indoor relative humidity in the room of Building A (Location A2) and Building B (Location B2). 
Referring to Figure 17, the overall light intensity at locations A2 and B2 did not comply with the acceptable value of $100 \mathrm{Lux}$ as recommended for a hotel room in MS 1525:2014. The mean light intensity at location A2 was 84.7 Lux compared to location B2 which was 54.2 Lux. Location A2 had a steady light intensity of 90 Lux in the morning and a slight decrease to 74.9 Lux on 2:30 p.m., followed by a rise to 82.8 Lux from 3:30 p.m. In addition, a slight drop could be noticed at location A2 in the evening due to the openings that allowed natural daylight to enter. On the other hand, the light intensity at location B2 increased from $43.3 \mathrm{Lux}$ at 8:00 a.m. to 59.1 Lux in the afternoon then dropped to 43.9 Lux in the evening.



Figure 17. Indoor light intensity in the room of Building A (Location A2) and Building B (Location B2).

Figure 18 shows the relationship between air velocity and time at locations A2 and B2. The mean air velocity at location A2 was $0.10 \mathrm{~m} / \mathrm{s}$, higher than the mean air velocity at location B2 at $0.03 \mathrm{~m} / \mathrm{s}$. The existence of operable windows at location A2 allowed for natural ventilation. The air velocity at location A2 fluctuated throughout the day with a maximum air velocity of $0.14 \mathrm{~m} / \mathrm{s}$ and a minimum of $0.03 \mathrm{~m} / \mathrm{s}$. On the other hand, the air velocity in location B2 remained steady with a range of 0.03-0.04 m/s. Generally, the air velocity at location B2 was not sufficient for occupants' comfort, while the air velocity in Building A was slightly higher than the optimum air velocity in the morning and evening according to the MS 1525:2014.

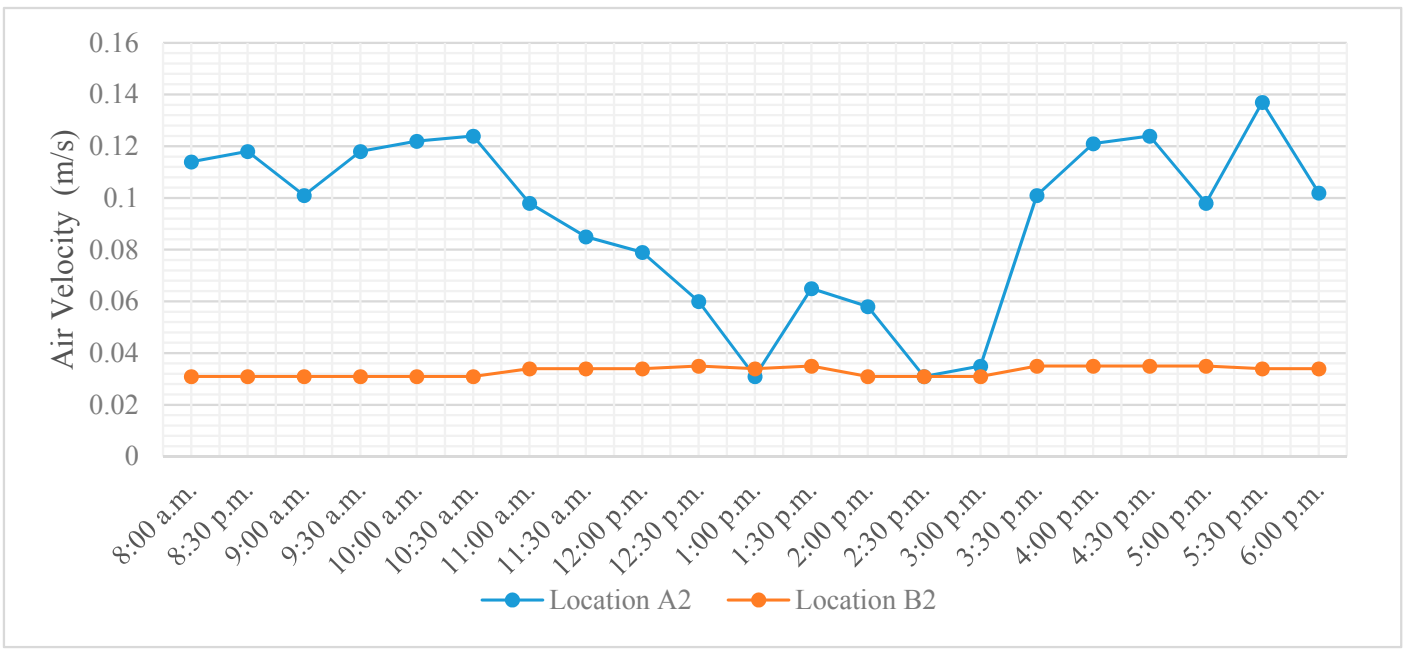

Figure 18. Indoor air velocity in the room of Building A (Location A2) and Building B (Location B2). 


\subsection{Occupants' Behaviour}

In this section, the data collected from the survey is analyzed to evaluate the occupants' satisfaction of the interior spaces. The preferred type of ventilation and lighting were analyzed in Building A and Building B according to three time periods of 08:00 a.m. to 11:00 a.m., 12:00 p.m. to 3:00 p.m. and 4:00 p.m. to $06: 00$ p.m. Results showed that $60 \%$ of the respondents agreed to the use of fans, while $40 \%$ agreed to the use of natural ventilation to ventilate the interior of Building A from 8:00 a.m. to $11: 00$ a.m. From 12:00 p.m. to 3:00 p.m., $40 \%$ of the respondents believed that air-conditioning is preferable instead. Subsequently, most respondents preferred fans and natural ventilation as the main type of ventilation from 4:00 p.m. to 6:00 p.m. On the contrary, respondents at Building B preferred to use air-conditioning from 8:00 a.m. to 6:00 p.m.

As for lighting, 55\% of respondents at Building A preferred natural daylight from 08:00 a.m. to 11:00 a.m. and this percentage went up to $90 \%$ for the period between 12:00 p.m. and 3:00 p.m. Between 4:00 p.m. and 6:00 p.m. however, only 40\% of respondents preferred the use of natural daylight. As observed at Building B, all respondents preferred the use of artificial lights in the morning (8:00 a.m.-11:00 a.m.) and evening (4:00 p.m.-6:00 p.m.) periods. During the afternoon, $60 \%$ of the respondents preferred the use of day-lighting.

\section{Discussion}

Through the analysis of the initial interview with physical survey, indoor environmental assessment, measurements of indoor environmental conditions and occupant survey, results show that Building A performed better than Building B in terms of its indoor environmental condition and functionality. Building A outperformed Building B in all sections of the indoor environmental assessment except for acoustics, where both buildings were very similar, non-existent water efficiency strategies at both buildings and the absence of an automatic controlled indoor air temperature system.

From the occupant survey, results show that most of Building A occupants were more satisfied with the indoor environmental conditions in terms of air quality and ventilation, while occupants at Building B were not convinced with indoor ventilation and lighting when there are no artificial lighting and air-conditioning. According to the survey and indoor environmental assessment findings, the indoor moisture is moderately controlled in both case studies. As for lighting and visual comfort, Building A promotes the use of natural light and energy saving lighting such as LED light which helps to improve the energy efficiency. It was found that the occupant preference depends on the location, as day-lighting is preferred on the upper floor, while artificial lights are preferred on the ground floor. However, the respondents were not satisfied with the lighting condition in Building B as there was no sufficient level of natural light due to the lack of operable windows. On the other hand, recycled materials used at Building A are more in line with the principle of Sustainability as compared to the use of new materials to replace the demolishment of the existing roof structure for the adaptive reuse renovation of Building B. In addition, the recycling practices in Building A promote sustainable use while it does not exist in Building $B$.

The measurement of indoor environmental conditions showed that mean indoor air temperatures of Building A were $31.92{ }^{\circ} \mathrm{C}$ at the lobby and $31.16^{\circ} \mathrm{C}$ in the hotel room that are higher than the MS 1525:2014 standard but the majority of respondents agreed that natural ventilation with the aid of light mechanical ventilation is preferred at Building A in the morning and evening while the air-conditioning only in the afternoon. This shows that thermal comfort can be achieved inside Building A. As for Building $\mathrm{B}$, the air-conditioning systems run throughout the day and the indoor temperature was stable and within the MS 1525:2014 optimum temperature range. Besides this, the RH level at the lobby of Building A and Building B was similar between 58\% and 73\%. The RH level in the rooms for both case studies maintained steadily at around $68 \%$ which is slightly above the requirement for comfort condition.

The light intensity at Building A was sufficient in the lobby with an average of 246.2 Lux with the use natural daylight aided by artificial lights. However, the light intensity in the rooms is not sufficient 
which observed to be below 85 Lux. Even worse, the light intensity in the hotel room of Building B was lower at only 54.2 Lux as compared to Building A due to deep plan design where windows are not provided and were not considered when this building underwent structural adaptation. Artificial lights are needed in Building B throughout the day. Most of the respondents believed in the need for artificial lighting, especially in the morning and evening while natural daylight could be utilized in particular areas during afternoons. Finally, the study found that Building A has an optimum level of air velocity in the lobby while the room was slightly above the comfort range. The data recorded readings between $0.15 \mathrm{~m} / \mathrm{s}$ and $0.50 \mathrm{~m} / \mathrm{s}$. On the other hand, the air velocity in Building B was lower than the standard comfort level, especially the hotel room.

\section{Conclusions}

This study highlighted that with careful consideration during the design stage of an adaptive reuse renovation, heritage buildings such as Building A can perform well after being renovated with a new usage. This is particularly important since many private heritage building owners in sustaining their incomes choose to change the usage of their buildings to meet the current demand to accommodate the growing tourism sector. This is manifested in the adaptive reuse of heritage shophouses not just in Jalan Sultan, Kuala Lumpur, but also, throughout the old Kuala Lumpur district, the Georgetown and Melaka UNESCO World Heritage Zones. Unlike Kuala Lumpur, heritage buildings in Georgetown and Melaka are well protected by laws in place to safeguard the UNESCO listing thus, building owners are more careful and building renovations and adaptive reuses are well-scrutinized by the authorities and relevant Non-Government Organisations. In addition to the situation in Kuala Lumpur, heritage buildings in other regional towns and cities are also vulnerable to callous adaptive reuse. Similar studies using the same methodology will be done in the future at more heritage buildings throughout the country, to further highlight that heritage buildings can indeed take on new functions and perform well in terms of their indoor environmental conditions and meet new demands and expectations. After all, reusing existing building structures and envelopes, maintaining thermal comfort indoors, and recycling furniture/building finishes, amongst other things, can bring more income to heritage building owners, and this is definitely in line with the principle of sustainability.

Author Contributions: This paper is to be attributed in equal parts to the authors.

Conflicts of Interest: The authors declare no conflict of interest.

\section{References}

1. Dewiyana, E.; Ibrahim, N.; Hajar, N.H. The Green Aspects of Adaptive Reuse of Hotel Penaga. Procedia Soc. Behav. Sci. 2016, 222, 631-643. [CrossRef]

2. Kerajaan Malaysia. Akta Warisan Kebangsaan 2005 (Akta 645); Kerajaan Malaysia: Kuala Lumpur, Malaysia, 2008.

3. The Commissioner of Law Revision Malaysia. Act 645 National Heritage Act 2005; PNMB: Kuala Lumpur, Malaysia, 2006; p. 14.

4. Shopsin, W.C. Restoring Old Buildings for Contemporary Uses: An American Sourcebook for Architects and Preservationists; Whitney Library of Design: New York, NY, USA, 1986.

5. Douglas, J. Building Adaptation; Routledge: London, UK, 2006.

6. Baker, N. The Handbook of Sustainable Refurbishment: Non-Domestic Buildings; Earthscan: London, UK, 2009.

7. Bromley, R.D.F.; Tallon, A.; Thomas, C.J. City centre regeneration through residential development: Contributing to sustainability. Urban Stud. 2005, 42, 2407-2429. [CrossRef]

8. Bullen, P.A. Adaptive reuse and sustainability of commercial buildings. Facilities 2007, 25, 20-31. [CrossRef]

9. Department of the Environment and Heritage. Preserving Our Past, Building Our Future; Department of the Environment and Heritage: Canberra, Australia, 2004.

10. Yung Esther, H.K.; Langston, C.; Chan, E.H.W. Adaptive reuse of traditional Chinese shophouses in government-led urban renewal projects in Hong Kong. Cities 2014, 39, 87-98. [CrossRef]

11. Rodwell, D. Conservation and Sustainability in Historic Cities; John Wiley \& Sons: New York, NY, USA, 2008. 
12. Yung, E.H.; Chan, E.H. Implementation challenges to the adaptive reuse of heritage buildings: Towards the goals of sustainable, low carbon cities. Habitat Int. 2012, 36, 352-361. [CrossRef]

13. Dian, A.M.; Abdullah, N.C. Public participation in heritage sites conservation in Malaysia: Issues and Challenges. Procedia Soc. Behav. Sci. 2013, 101, 248-255. [CrossRef]

14. Watson, P. The key issues when choosing adaptation of an existing building over new build. J. Build. Appraisal 2009, 4, 215-223. [CrossRef]

15. Gurstein, P. Malaysian Architectural Heritage Survey: A Handbook; Badan Warisan Malaysia: Kuala Lumpur, Malaysia, 1990.

16. Loo, Y.M. Architecture and Urban Form in Kuala Lumpur: Race and Chinese Spaces in a Postcolonial City; Ashgate Publishing, Ltd.: Aldershot, UK, 2013.

17. Tan, Y.W. Penang Shophouses: A Handbook of Features and Materials; Tan Yeow Wooi Culture and Heritage Research Studio: Grorge Town, Malaysia, 2015.

18. Department of Statistics Malaysia. Press Release Tourism Satellite Account 2015. Available online: https://www.dosm.gov.my/v1/uploads/files/1_Articles_By_Themes/National\%20Accounts / TSA/Tourism\%20Satellite\%20Account,\%202010-2015.pdf (accessed on 10 October 2017).

19. Hall, C.M.; Gossling, S.; Scott, D. (Eds.) The Routledge Handbook of Tourism and Sustainability; Routledge: London, UK, 2015.

20. Swarbrooke, J. Sustainable Tourism Management; CABI: New York, NY, USA, 1999.

21. Penner, R.H.; Adams, L.; Rutes, W. Hotel Design, Planning and Development; Routledge: London, UK, 2013.

22. Hannam, K.; Diekmann, A. (Eds.) Beyond Backpacker Tourism: Mobilities and Experiences; Channel View Publications: Bristol, UK, 2010; Volume 21.

23. Remøy, H.T.; van der Voordt, T.J.M. A new life: conversion of vacant office buildings into housing. Facilities 2007, 25, 88-103. [CrossRef]

24. Conejos, S.; Langston, C.; Smith, J. Enhancing sustainability through designing for adaptive reuse from the outset: A comparison of adaptSTAR and Adaptive Reuse Potential (ARP) models. Facilities 2015, 33, 531-552. [CrossRef]

25. Latham, D. Creative Reuse of Buildings; Donhead: Shaftesbury, UK, 2000.

26. Wilkinson, S.; Reed, R.; Kimberley, J. Using building adaptation to deliver sustainability in Australia. Struct. Surv. 2009, 27, 46-61. [CrossRef]

27. Fournier, D.; Zimnicki, K. Integrating Sustainable Design Principles into the Adaptive Reuse of Historical Properties; U.S. Army Corps of Engineers: Washington, DC, USA, 2004.

28. Snyder, G.H. Sustainability through Adaptive Reuse: The Conversion of Industrial Building. Unpublished Master's Thesis, University of Cincinnati, Cincinnati, OH, USA, 2005.

29. Conejos, S.; Langston, C.; Chan, E.H.; Chew, M.Y. Governance of heritage buildings: Australian regulatory barriers to adaptive reuse. Build. Res. Inf. 2016, 44, 507-519. [CrossRef]

30. Ignjatovic, N.C.; Ignjatovic, D. Possibilities for upgrading the existing building stock in Belgrade. Manag. Environ. Qual. Int. J. 2006, 17, 527-537. [CrossRef]

31. Kersting, J.M. Integrating past and present: The story of a building through adaptive reuse. Master's Thesis, University of Cincinnati, Cincinnati, OH, USA, 2006.

32. Frattari, A.; Lawrence, D. Envelope within an envelope: An FM approach to adaptive re-use of redundant barns. Facilities 2007, 25, 127-136. [CrossRef]

33. Fianchini, M. Fitness for purpose. A performance evaluation methodology for the management of university buildings. Facilities 2007, 25, 137-146. [CrossRef]

34. Arup. Existing Buildings. Survival Strategies; Arup: Melbourne, Australia, 2008.

35. Mısırlısoy, D.; Günçe, K. Adaptive reuse strategies for heritage buildings: A holistic approach. Sustain. Cities Soc. 2016, 26, 91-98. [CrossRef]

36. Geraedts, R.P.; Van der Voordt, D.J.M. A Tool to Measure Opportunities and Risks of Converting Empty Offices into Dwellings. In Sustainable Urban Areas; ENHR: Rotterdam, The Netherland, 2007.

37. Wilkinson, S.J. The Relationship between Building Adaptation and Property Attributes. Ph.D. Thesis, Deakin University, Deakin, Australia, 2011.

38. Green Building Index (GBI) Non-Residential Existing Building (NREB), 2011. Available online: http:/ / new.greenbuildingindex.org/Files/Resources/GBI\%20Tools/GBI\%20NREB\%20Non-Residential\% 20Existing\%20Building\%20Tool\%20V1.1\%20Final.pdf (accessed on 19 August 2016). 
39. Munaaim, M.A.; Al-Obaidi, K.M.; Ismail, M.R.; Abdul Rahman, A.M. Potential of fibre optic daylighting systems in tropical Malaysia. Indoor Built Environ. 2016, 25, 466-480. [CrossRef]

40. Al-Obaidi, K.M.; Ismail, M.A.; Abdul Rahman, A.M. Assessing the allowable daylight illuminance from skylights in single-storey buildings in Malaysia: A review. Int. J. Sustain. Build. Technol. Urban Dev. 2015, 6, 236-248. [CrossRef]

41. Al-Obaidi, K.M.; Ismail, M.A.; Abdul Rahman, A.M. Effective use of hybrid turbine ventilator to improve thermal performance in Malaysian tropical houses. Build. Serv. Eng. Res. Technol. 2016, 37, 755-768. [CrossRef]

42. Al-Obaidi, K.M.; Munaaim, M.A.; Ismail, M.A.; Rahman, A.M. Designing an integrated daylighting system for deep-plan spaces in Malaysian low-rise buildings. Sol. Energy 2017, 149, 85-101. [CrossRef]

(C) 2017 by the authors. Licensee MDPI, Basel, Switzerland. This article is an open access article distributed under the terms and conditions of the Creative Commons Attribution (CC BY) license (http:// creativecommons.org/licenses/by/4.0/). 